\title{
Genetic Diversity Analysis of Rice Genotypes for Yield and Yield Attributing Traits under Saline Stress Condition
}

\author{
R. Madhuri ${ }^{*}$, B.M. Dushyanthakumar ${ }^{1}$, S.L. Krishnamurthy ${ }^{2}$, G.T. Navya ${ }^{1}$, \\ S. Gangaprasad ${ }^{1}$, B.I. Halingali ${ }^{3}$ and B.C. Dhannajaya ${ }^{3}$ \\ ${ }^{1}$ Department of Genetics and Plant Breeding, College of Agricultural, Navile, University of \\ Agricultural and Horticultural Sciences, Shivamogga, India \\ ${ }^{2}$ Division of Crop improvement, ICAR- ICAR-Central Soil Salinity Research Institute, Karnal, \\ Haryana, India \\ ${ }^{3}$ College of Agricultural, Navile, University of Agricultural and Horticultural Sciences, \\ Shivamogga, India \\ *Corresponding author
}

\section{A B S T R A C T}

The present investigation to assess genetic diversity among 100 rice genotypes including five checks was conducted at Thyavanagi Village of Davanagere,

\section{Keywords}

Rice (Oryza sativa

L.), Genetic

Diversity,

Genotypes

\section{Article Info}

Accepted:

15 June 2019

Available Online:

10 July 2019
Karnataka during Kharif 2016. Mahalanobis' $D^{2}$ statistics is used to quantify the degree of divergence. It is based on second degree statistics and pattern obtained by $\mathrm{D}^{2}$ does not change with number of characters. Mean values of 100 rice genotypes for ten characters were used to assess genetic distance between pair of genotypes. Genotypes were grouped into eleven clusters distribution patterns. Cluster pattern indicated that cluster I consists of maximum of 33 genotypes followed by cluster III (18 genotypes), cluster V (12 genotypes), cluster IV (11 genotypes), cluster II (10 genotypes). Whereas, clusters VIII, IX and XI were clustered as unitary clusters with single genotypes. Maximum intra cluster distance was observed in cluster VII (1055.02) followed by cluster IV (715.11) and cluster VI indicated that the genotypes grouped under these clusters were more diverse. Highest contribution towards divergence was observed by plant height $(58.94 \%)$ followed by spikelet fertility $(17.25 \%)$.

\section{Introduction}

Rice (Oryza sativa L.) is one of the important staple food crop consumed by two third of the world wide population and a major contributor to national food security. With the increased population the demand for rice is also increasing in accordance. Asia accounts for 90 per cent of world's rice area and 92 per cent of world's rice production (Dhillon et al., 2010). Rice is affected by various abiotic stresses among them salinity is the second most 
devastating phenomenon after drought and interfering with the production and yield of rice globally. Salinity is the condition of the soils where electrical conductivity (EC) more than $4 \mathrm{dSm}^{-1}$, exchangeable sodium percentage (ESP) less than 15 and $\mathrm{pH}$ less than 8.5 . Being a glycophyte, by nature rice is susceptible to salinity and show vivid response against the detrimental effects of increased salt accumulation.

Globally $953 \mathrm{~m}$ ha area is affected by salinity and sodicity which nearly accounts for 20 per cent of cultivable land and half of the total irrigated land. Maximum salt affected area is in Australia followed by north and central Asia and South America. Total of $6.73 \mathrm{~m}$ ha of productive land is affected by salt. In India, Gujarat state has maximum area of salt affected soils followed by West Bengal and Rajasthan which account for about 64.50 per cent. In Karnataka around $0.189 \mathrm{~m}$ ha area is affected by salt. It has been further projected that $11.7 \mathrm{~m}$ ha area will be affected by 2025 (Singh, 2018).

Rice has been cultivated in India across ages under wide range of latitudes. Rice covers an area of $149.15 \mathrm{~m}$ ha with 550.19 million tonnes. In India cultivated across an area of 44.6 million ha with 23 per cent of total world rice production and 45 per cent of the total Indian food grain production. India ranks first in area and second in production following China, the largest producer of rice. In Karnataka, rice is cultivated in an area of 1.39 $\mathrm{m}$ ha with 4.05 million tonnes of production annually and productivity of $2.92 \mathrm{t} / \mathrm{ha}$ (Anonymous, 2018).

Genetic diversity among the genotypes serves as a way to adapt to changing environments and their utilization in crop improvement programme. With more genetic variation, the individuals in a population will possess variations of alleles that are suited for the salt tolerance. Understanding the genetic architecture of the populations is necessary to formulate efficient screening techniques for salt tolerance as it is a polygenic trait. Narrow sense heritability and environmental influence of salt tolerance trait interfere with the conventional screening methods (Gregorio, 1997) which helps to develop systematic breeding programme through the utilization of large spectrum of genetic variability among the genotypes.The objectives of this study were to characterize rice genotypes with adaptations to saline soils for their genetic diversity using morphological traits.

\section{Materials and Methods}

The experimental material for the present study comprised of 100 rice genotypes which includes indigenous collection, released varieties, lines developed from different breeding strategies were collected from different sources maintained at Department of Genetics and Plant Breeding, College of Agriculture, University of Agricultural and Horticultural Sciences, Shivamogga and ICAR- Central Soil Salinity Research Institute at Karnal, Haryana. 100 rice genotypes along with five checks were sown in the nursery bed during Kharif2016 with recommended cultural practices. Twenty one days old seedlings were transplanted saline field conditions ( $\mathrm{pH}: 8.09$, EC: $5.46 \mathrm{dSm}^{-1}$, ESP: 9.17) at Thyavanagi village of Davanagere, Karnataka with spacing of $0.3 \times 0.1 \mathrm{~m}$ in Randomised Complete Block Design (RCBD) with two replications.

Observations on days to 50 per cent flowering, datys to maturity, plant height $(\mathrm{cm})$, number of tillers/plant, number of productive tillers/plant, panicle length $(\mathrm{cm})$, spikelt fertility (\%), chlorophyll content $(\mathrm{mg} / \mathrm{ml})$, 1000 grain weight $(\mathrm{g})$, grain yield (g/plant) and $\mathrm{L} / \mathrm{B}$ ratio were recorded based on five randomly selected plants. Mahalanobis' (1936) $\mathrm{D}^{2}$ statistic was used for assessing the 
genetic divergence between populations. $\mathrm{D}^{2}$ analysis was done by using the WINDOSTAT version 9.2 software. Genetic distance was estimated using Tocher's method (Rao, 1952).

\section{Results and Discussion}

Nature and magnitude of genetic diversity exists in the crop species will be utilized for formulating breeding programme. Mahalanobis' $\mathrm{D}^{2}$ statistics is used to quantify the degree of divergence. It is based on second degree statistics and pattern obtained by $\mathrm{D}^{2}$ does not change with number of characters. Mean values of 100 rice genotypes for ten characters were used to assess genetic distance between pair of genotypes. Genotypes were grouped into eleven clusters distribution patterns presented in Table 1. Out of eleven clusters, VIII, IX and XI were three solitary clusters indicated the uniqueness of those genotypes. Whereas, cluster I consists of maximum33 genotypes followed by cluster III (18 genotypes), cluster V (12 genotypes), cluster IV (11 genotypes), cluster II (10 genotypes). Similar results are observed by Lahari et al., (2017) and Kumari et al., (2018).

Intra and inter cluster distances for 100 rice genotypes were furnished in Table 3 . Maximum intra cluster distance was observed in cluster VII (1055.02) followed by cluster V (712.11) and cluster VI (654.17) indicated that the genotypes grouped under these clusters were more diverse. The lower intra cluster distance was recorded in cluster I (379.31) depicts that the genotypes in this cluster are less diverse. Whereas, three solitary clusters were identified (clusters VIII, IX and XI). Results are in accordance with Kaliyamoorthy et al., (2013) and Lahari et al., (2017).

Highest inter cluster distances was observed between clusters V and III (50245.49) followed by cluster $X$ and VI (8993.19) indicated that diversity of genotypes between these two clusters is high. Lowest inter cluster distance was recorded between cluster VIII and XI (386.38) followed by cluster III and I (815.09). Similar results were observed by Nirosha et al., (2016) and Kumari et al., (2018). Presence of single genotype in a cluster indicates uniqueness of that genotype from other genotypes. Higher intra cluster distance indicates that genotypes in the respective clusters and the higher inter cluster distances have wider genetic distances between the genotypes which could be used in hybridization programme.

Cluster mean analysis was calculated using Tocher's method for ten yield and its attributing traits and presented in Table 4. Higher cluster mean for days to 50 per cent flowering was observed in cluster VI (127.00) followed by cluster X (117.25) and cluster III (111.67). Whereas, lowest cluster mean was recorded in cluster XI (93.00). For plant height higher cluster mean was recorded in cluster X (167.45) followed by cluster III (147.60) and cluster VI (138.07) and lower cluster mean in cluster II (94.18). Highest and lowest cluster mean for number of tillers per plant was recorded in cluster VII (16.63) and cluster X (10.85), respectively.

Regarding the number of productive tillers per plant highest cluster mean was observed in cluster V (11.93) followed by cluster IX (11.80) and lowest cluster mean was recorded in cluster X (8.25). For panicle length highest cluster mean was recorded in cluster IX (24.28) and lowest in cluster VI (20.83). Highest and lower cluster mean for spikelet fertility was recorded in cluster XI (82.46) and cluster IX (46.67), respectively. Whereas, test weight recoded highest cluster mean was recorded in cluster VIII (27.63) followed by cluster XI (25.81) and lowest cluster mean in cluster IX (16.78). For grain yield/plant was recorded highest cluster mean in cluster XI (32.64) and lowest in cluster IX (4.98). 
Table.1 Grouping of 100 rice genotypes along with five checks based on $\mathrm{D}^{2}$ clustering method evaluated during Kharif2016 for yield and related traits under saline condition

\begin{tabular}{|c|c|c|}
\hline Cluster & $\begin{array}{c}\text { No. of } \\
\text { Genotypes }\end{array}$ & Genotypes \\
\hline I & 33 & $\begin{array}{l}\text { IR-4106,Kempukar, Kabbaga, Magadsugandha, PR123, IET- } \\
\text { 19111, PS-2,Peetasale,Hejjebetta,BJ-1, Ambemohari, Anekombu, } \\
\text { IET-19370,IET-19120, Benaka, IET-18909,Arundathi, } \\
\text { Halagabatta, Balesuli, Chandasubogha, PS-3 Dabbanasale, IET- } \\
\text { 18862, Somasale, Giddabatta, P. Kirvani, HR mysore, Halubilu, } \\
\text { IET-19760, Kaisari, Doddi, Pusa-44, Amrutha }\end{array}$ \\
\hline II & 10 & $\begin{array}{l}\text { Sarjoo-52, Siddasanna,Jyothi,Suhasa, Nareminda,Ragoli, IET- } \\
\text { 21132, Suvarna, CSR-11, CSR-10 }\end{array}$ \\
\hline III & 18 & $\begin{array}{l}\text { Onamaradinellu, P.Doddi,Karidadi, Msaleputtabatta, Suma, PS-5, } \\
\text { Pankaj, PMB-61, Barmablack, Maskat, Doodalur, Nesara, } \\
\text { Pokkali, SR-26B, Karna, Kishora, Edikuni, Bilikannuhegga }\end{array}$ \\
\hline IV & 11 & $\begin{array}{l}\text { Challi, CSR-46, Hugudi, Valtiga, Udarasali, Natiijaddu, Budda, } \\
\text { Lalneeth, Ankursona, Bilijaddu,Bora }\end{array}$ \\
\hline $\mathbf{V}$ & 12 & $\begin{array}{l}\text { Doddaabhilasha, Ubarmunda, Kartha, Halugdda, Koloniya, PR- } \\
\text { 121, Gowdragadala, IET-19886, CSR-36, CSR-27, CSR-30, IET- } \\
18892\end{array}$ \\
\hline VI & 6 & $\begin{array}{l}\text { Chippiga, Haldoddiga, Culture, Kempusanna, Lunishree, } \\
\text { Diamondsona }\end{array}$ \\
\hline VII & 8 & $\begin{array}{l}\text { Ponni, PUBM8, CSR-13, IET-21468, Pusa-1121, CSR-43,CSR- } \\
55, \text { PB-1 }\end{array}$ \\
\hline VIII & 1 & CSR-23 \\
\hline IX & 1 & Masuribatta \\
\hline $\mathbf{X}$ & 4 & Dambarsali, Kavalakannu, Halagidda, Halaga \\
\hline $\mathbf{X I}$ & 1 & CSR-66 \\
\hline
\end{tabular}

Table. 2 Per cent contribution of yield and yield related characters towards divergence of rice genotypes under saline condition

\begin{tabular}{|c|l|c|}
\hline Sl. No. & \multicolumn{1}{|c|}{ Characters* } & Contribution (\%) \\
\hline $\mathbf{1}$ & Plant height $(\mathrm{cm})$ & $58.94 \%$ \\
\hline $\mathbf{2}$ & Spikelet fertility (\%) & $17.25 \%$ \\
\hline $\mathbf{3}$ & Days to 50\% flowering & $14.63 \%$ \\
\hline $\mathbf{4}$ & Grain yield/plant $(\mathrm{g})$ & $7.25 \%$ \\
\hline $\mathbf{5}$ & Days to maturity & $0.97 \%$ \\
\hline $\mathbf{6}$ & Test weight $(\mathrm{g})$ & $0.77 \%$ \\
\hline $\mathbf{7}$ & Number of tillers/plant & $0.13 \%$ \\
\hline $\mathbf{8}$ & Panicle length $(\mathrm{cm})$ & $0.05 \%$ \\
\hline
\end{tabular}

Other characters have negligible contribution towards total divergence 
Table.3 Average intra and inter cluster distance values of rice genotypes for yield and yield attributing traits under saline condition

\begin{tabular}{|c|c|c|c|c|c|c|c|c|c|c|c|}
\hline & $\begin{array}{c}\text { Cluster } \\
\text { I }\end{array}$ & $\begin{array}{c}\text { Cluster } \\
\text { II }\end{array}$ & $\begin{array}{c}\text { Cluster } \\
\text { III }\end{array}$ & $\begin{array}{c}\text { Cluster } \\
\text { IV }\end{array}$ & $\begin{array}{c}\text { Cluster } \\
\text { V }\end{array}$ & $\begin{array}{c}\text { Cluster } \\
\text { VI }\end{array}$ & $\begin{array}{c}\text { Cluster } \\
\text { VII }\end{array}$ & $\begin{array}{c}\text { Cluster } \\
\text { VIII }\end{array}$ & $\begin{array}{c}\text { Cluster } \\
\text { IX }\end{array}$ & $\begin{array}{c}\text { Cluster } \\
\text { X }\end{array}$ & $\begin{array}{c}\text { Cluster } \\
\text { XI }\end{array}$ \\
\hline Cluster I & 379.31 & 2123.64 & 815.09 & 889.08 & 979.67 & 1658.80 & 3427.79 & 2640.75 & 1291.72 & 2102.90 & 1224.66 \\
\hline Cluster II & & 520.27 & 3931.79 & 1884.80 & 1863.13 & 4483.00 & 1222.26 & 946.56 & 2360.29 & 6797.65 & 1057.67 \\
\hline Cluster III & & & 494.50 & 1369.93 & 50245.49 & 1415.70 & 5714.62 & 4600.93 & 1406.31 & 971.08 & 2555.58 \\
\hline Cluster IV & & & & 634.42 & 1963.95 & 2788.27 & 3846.04 & 2073.70 & 1046.21 & 2803.84 & 1129.79 \\
\hline Cluster V & & & & & 712.11 & 2360.84 & 2284.20 & 2506.59 & 2507.92 & 4025.10 & 1344.06 \\
\hline Cluster VI & & & & & & 654.17 & 5251.06 & 6652.48 & 1495.10 & 1776.80 & 4424.98 \\
\hline Cluster VII & & & & & & & 1055.02 & 2296.64 & 4026.22 & 8993.19 & 2462.55 \\
\hline Cluster VIII & & & & & & & & 0.00 & 3921.20 & 7882.65 & 386.38 \\
\hline Cluster IX & & & & & & & & & 0.00 & 2327.42 & 2712.72 \\
\hline Cluster X & & & & & & & & & & 614.95 & 5105.34 \\
\hline Cluster XI & & & & & & & & & & & 0.00 \\
\hline
\end{tabular}

*Diagonal values indicate intra cluster distances and above diagonal values indicate inter cluster distances 
Table.4 Cluster means for yield and yield attributing traits of 100 rice genotypes along with five checks under saline condition

\begin{tabular}{|c|c|c|c|c|c|c|c|c|c|c|}
\hline & $\begin{array}{c}\text { Days to } \\
50 \% \\
\text { lowering }\end{array}$ & $\begin{array}{c}\text { Plant } \\
\text { height } \\
(\mathrm{cm})\end{array}$ & $\begin{array}{c}\text { No. of } \\
\text { tillers/pla } \\
\text { nt }\end{array}$ & $\begin{array}{c}\text { No. of } \\
\text { productive } \\
\text { tillers/plant }\end{array}$ & $\begin{array}{l}\text { Panicle } \\
\text { length } \\
\text { (cm) }\end{array}$ & $\begin{array}{c}\text { Spikelet } \\
\text { fertility } \\
(\%)\end{array}$ & $\begin{array}{c}\text { Test } \\
\text { weight } \\
\text { (g) }\end{array}$ & $\begin{array}{c}\text { Grain } \\
\text { yield } \\
\text { /plant } \\
(\mathrm{g})\end{array}$ & $\begin{array}{c}\mathrm{L} / \mathrm{B} \\
\text { ratio }\end{array}$ & $\begin{array}{c}\text { Days to } \\
\text { maturity }\end{array}$ \\
\hline Cluster II & 96.30 & 94.18 & 14.30 & 10.76 & 22.14 & 64.50 & 20.90 & 12.94 & 2.55 & 125.30 \\
\hline Cluster IV & 95.73 & 130.71 & 12.67 & 9.29 & 23.11 & 68.96 & 21.67 & 14.02 & 2.33 & 125.73 \\
\hline Cluster V & 115.00 & 110.35 & 15.07 & 11.93 & 21.48 & 78.19 & 21.31 & 23.89 & 2.53 & 144.83 \\
\hline Cluster VIII & 84.00 & 95.60 & 14.00 & 11.00 & 22.60 & 80.95 & 27.63 & 23.67 & 2.75 & 114.00 \\
\hline Cluster IX & 104.00 & 134.00 & 13.00 & 11.80 & 24.28 & 46.67 & 16.78 & 4.98 & 2.61 & 134.00 \\
\hline Cluster X & 117.25 & 167.45 & 10.85 & 8.25 & 23.55 & 68.37 & 21.26 & 15.84 & 2.63 & 147.25 \\
\hline Cluster XI & 93.00 & 109.80 & 13.80 & 10.40 & 21.75 & 82.46 & 25.81 & 32.64 & 2.24 & 123.00 \\
\hline
\end{tabular}


Regarding days to maturity highest and lowest cluster mean was observed in cluster VI (157.00) and cluster VIII (114.00), respectively. Highest cluster mean for L/B ratio was recorded in cluster VIII (2.75) with lowest cluster mean in cluster XI (2.24). Similar results are emphasized by Rathod et al., (2017) and Rashid et al., (2017). Cluster mean analysis is used to identify clusters having varying levels of variability for the characters studied and to identify clusters having less diversity for more number of characters. Clusters with higher cluster mean can be utilized in breeding programme for yield in desirable direction.

Contribution of different yield and related characters towards total divergence was assessed and represented in Table 2. Highest contribution towards divergence was observed by plant height $(58.94 \%)$ followed by spikelet fertility $(17.25 \%)$ days to 50 per cent flowering $(14.63 \%)$, grain yield/plant $(7.25 \%)$, days to maturity $(0.97 \%)$, test weight $(0.77 \%)$, number of tillers per plant $(0.13 \%)$ and panicle length $(0.05 \%)$. Similar results are reported by Kumari et al., (2018) and Raghavendra et al., (2018). Hence these genotypes can be efficiently used for hybridization programme to develop high yielding salinity tolerance varieties.

\section{References}

Anonymous, 2018 , http://agricoop.nic.in/agristatistics.htm.

Dhillon, B. S., Kataria, P. and Dhillon, P. K., 2010, National food security vis-a vis sustainability of agriculture in high crop productivity regions. Curr. Sci., 98: 3336.

Gregorio, G. B., Senadhira, D. and Mendoza, R. D., 1997. Screening rice for salinity tolerance. IRRI Discussion Paper Series No.22:1-30. International Rice Research Institute, Los Baños.
Kaliyamoorthy, S., Thirumeni, S., Paramasivam, K. and Nadaradjan, S., 2013, Genetic diversity analysis of rice (Oryza sativa) genotypes for seedling characters under saline - alkaline condition. Electronic J. Plt. Breed., 4(1): 1034-1042.

Kumari, P., Archana, D., Ranjan, D., Saket, D., Ram Kand, D. K. and Dwivedi, 2018, Genetic divergence in indigenous and exotic Rice (Oryza sativa L.) under Saline-Alkali Condition. Int.J.Curr.Microbiol.App.Sci., 7: 45464553.

Lahari, P., Dushyanthakumar, B. M. and Raghavendra, P., 2017, Genetic diversity for grain yield and its components in rice (Oryza sativa L.) genotypes under submergence. Electronic J. Pl. Breed., 5(1): 67-70.

Mahalanobis, P. C., 1936, on the generalized distance in statistics. Proc. Natl. Acad. Sci., 2: 55-79.

Nirosha, R. Thippeswamy, I, S., Ravindrababu, V. Ram Reddy, V. and Spandana, B., 2016, Genetic diversity analysis of Zinc, Iron, Grain Protein content and yield components in Rice. Electronic J. Pl. Breed., 7(2): 371-377.

Raghavendra, P., Dushyanthakumar, B. M., Madhuri, R. and Sachin, B. M., 2018. Exploitation of genetics of salinity tolerance in rice land races (Oryza sativa L.). J. Micro. Biol. 14(2): 128136.

Rao, C. R., 1952. Advanced statistics methods in biometry, John Wiley, New York, pp: 357-369.

Rashid, M.M., Hassan, L. and Begum, S.N., 2017. Phenotypic performance of rice landraces under salinity stress in reproductive stage. Progress Agric., 28(1): 1-6.

Rathod, A. J., Mistry, P. M., Pampaniya, A. G., Patel, H. R. and Chetariya, C. P., $2017, D^{2}$ statistics for grain yield and 
quality traits in Rice (Oryza sativa L.). Int. J. Pure App. Biosci., 5(4): 54-58.

Singh, G., 2018. Climate change and sustainable management of salinity in agriculture. Research in medical and engineering sciences, 6(2): 1-7.

\section{How to cite this article:}

Madhuri, R., B.M. Dushyanthakumar, S.L. Krishnamurthy, G.T. Navya, S. Gangaprasad, B.I. Halingali and Dhannajaya, B.C. 2019. Genetic Diversity Analysis of Rice Genotypes for Yield and Yield Attributing Traits under Saline Stress Condition. Int.J.Curr.Microbiol.App.Sci. 8(07): 1952-1959. doi: https://doi.org/10.20546/ijcmas.2019.807.232 